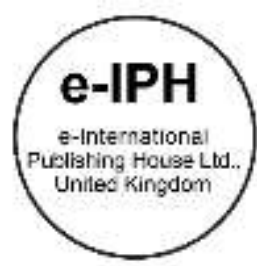

\title{
From Waste to Renewable Energy: The Potential of Value and Wealth Creation from Sewage Sludge
}

\author{
Azzah Amran, Saripah Abdul Latif \\ Faculty of Business and Management, \\ Universiti Teknologi MARA Kelantan, Kota Bahru Campus, Malaysia \\ azzahamran@kelantan.uitm.edu.my, saripah@kelantan.uitm.edu.my
}

\begin{abstract}
Issues and problems in waste management and renewable energy are often linked to development and industrialization. Their implication to people and the environment remain as global issue, particularly in developing countries like Malaysia. This study aims to look into the potential of value and wealth creation by transforming sewage sludge into new source of renewable energy. This study is using qualitative measures. The finding from this qualitative study reveals that, there is a potentiality of value and wealth creation by transforming sewage sludge into energy. Hopefully, this will contribute to green economy practices, which will eventually lead to sustainability of the environment.
\end{abstract}

Keywords: Renewable Energy; Waste; Wealth; Sustainability

eISSN: 2398-4287 @ 2018. The Authors. Published for AMER ABRA cE-Bs by e-International Publishing House, Ltd., UK. This is an open access article under the CC BYNC-ND license (http://creativecommons.org/licenses/by-nc-nd/4.0/). Peer-review under responsibility of AMER (Association of Malaysian Environment-Behaviour Researchers), ABRA (Association of Behavioural Researchers on Asians) and cE-Bs (Centre for Environment-Behaviour Studies), Faculty of Architecture, Planning \& Surveying, Universiti Teknologi MARA, Malaysia.

https://doi.org/10.21834/e-bpj.v3i9.1487

\subsection{Introduction}

Waste generated in Malaysia can be categorized into seven types namely: municipal solid waste (MSW), sewage, mining waste, construction waste, scheduled and hazardous waste, agriculture waste and radioactive waste. Sewage is characterized in terms of its physical, chemical and biological composition. As populations increase by leaps and bounds, it places more pressure on the environment and threatening sources of fresh water supplies. It was recognized that the problem of 'human waste' needed proper management.

According to Indah Water Konsortium (IWK) 2018, from the early 1900s there has been a steady evolution of sewage treatment into today's modern sewage treatment plants producing high quality effluent, which can be safely discharged to the environment or reused. More recent developments in sewage treatment have been to improve the reliability and efficiency of treatment systems to treat sewage to meet standards and reduce the land area occupied by treatment works through accelerating natural treatment rates under controlled conditions.

There are many regulatory measures and policy directions in place for managing waste with multiple goals to reduce waste generation per capita and to turn waste into a source of wealth through waste recovery for material extraction and conversion of waste to energy. The Green Technology Master Plan of Malaysia 2016 has outlined that waste management in Malaysia is largely driven by the public sector, supported by a regulatory framework, which governs the generation, storage, collection, transfer and transport, treatment and disposal of waste.

Based on the Green Technology Master Plan of Malaysia 2016, renewable Energy (RE) resources are diverse and they could come from large hydro, solar photovoltaic, biogas, biomass and small hydro. In the Tenth Malaysia Plan (RMK-10), the Government targeted 985 Mega Watt (MW) from RE generation by 2015. The total approved capacity in year 2014 is 6,285.24 MW.

Issues and problems in waste generation and renewable energy are often linked to development and industrialization, and its implication to people and the environment remains a global issue, particularly in developing countries. Population, rapid economic growth

eISSN: 2398-4287 ( 2018. The Authors. Published for AMER ABRA cE-Bs by e-International Publishing House, Ltd., UK. This is an open access article under the CC BYNC-ND license (http://creativecommons.org/licenses/by-nc-nd/4.0/). Peer-review under responsibility of AMER (Association of Malaysian Environment-Behaviour Researchers), ABRA (Association of Behavioural Researchers on Asians) and cE-Bs (Centre for Environment-Behaviour Studies), Faculty of Architecture, Planning \& Surveying, Universiti Teknologi MARA, Malaysia.

https://doi.org/10.21834/e-bpj.v3i9.1487 
and changes in lifestyle have resulted in the complexity of the waste composition being generated and contributed to the ever-increasing waste generation per capita. In managing the hazardous issues that come out from the waste management, various government policies has been outlined to overcome the problems.

Thus, from the current scenarios, this study is intended to explore the possible solutions in waste management and generation of renewable energy and its potential of value and wealth creation from a particular waste, which is sewage sludge.

\subsection{Literature Review}

The process of greening Malaysia's economy had started around 1970s with the introduction of regulations to manage pollution from the palm oil industry. Malaysia's policy framework in energy development gradually developed by focusing on fossil fuel supply in the 1970s is to a diversification of supply sources (renewable energy) by the year 2000. Currently, Malaysia has taken the initial step to embrace Green Technology through the National Green Technology Policy (NGTP), which was unveiled by the Prime Minister on 24th July 2009. The Policy focuses on four pillars, namely energy, environment, economy and social.

According to the previous Minister of Energy, Datuk Seri Panglima Dr Maximus Johnity Ongkili, Malaysia is anticipated that by 2030, green businesses will contribute approximately $1.5 \%$ to the nation's Gross Domestic Product (GDP) or equivalent to RM60 billion from RM7.9 billion in 2013 (Malaysia Technology Master Plan 2016). Thus, understandably that waste management and transformation of waste into renewable energy has potential in creating value. This projection is supported by Government's commitment towards realizing the green targets, proper execution of policies and monitoring mechanism to keep track of green business performance, increase of exports as well as cooperation from private sectors. This will also contribute to RM94.3 billion of total investment in green technology.

Since 2009 in Malaysia, several initiatives on renewable energy have shown that green technology could be instrumental in decoupling economic growth from natural capital depletion. This is reflected in the contribution to GDP made by the adoption and use of green technology based practices, systems and products, which are energy $63.1 \%$ water $1.5 \%$ waste $20.1 \%$ building $13.1 \%$ transport $2.2 \%$ respectively. This is indicator that shows Malaysia is a country that is aligning the direction to greener environment and sustainability in waste management system. The transformation of waste to thermal energy plants in 2030 is an indicator of the country's plan towards sustainability. In addition to this, Malaysia Technology Master Plan (2016) has outlined that in 2020, the country will at least has 1 waste to energy thermal plant in Malaysia.

According to a survey conducted in Malaysia on solid waste composition, characteristics and existing practice of solid waste recycling in Malaysia in 2013, $51 \%$ of waste generated comprised biodegradable waste, which included food waste, garden waste, wood and husk. $81 \%$ of the biodegradable waste disposed at landfills has since decomposed in an anaerobic condition producing large volumes of methane. This methane issues contribute to the sustainability issues. Methane is a primary source of Green House Gas (GHG) emissions in the waste sector, contributing to $23 \%$ of the total GHG emissions in Malaysia, of which $90.9 \%$ were generated from landfills, $8.6 \%$ from palm oil mill effluent (POME) and just under $1 \%$ were generated from bio-effluent. (Malaysia Energy Policy, 2016)

In addition to this, the renewable energy issues are mainly derived from the cost of electricity supply industry in Malaysia which is still considered as over-dependent on fossil fuel. Approximately $90 \%$ of overall generation mix attributed to coal and natural gas. The inevitable gas price increase for power generation and efforts towards achieving market prices has caused a major shift in the generation mix while coal on the other hand, has been more economically attractive source as least cost option and for base load to ensure the electricity prices are affordable without compromising security aspects. Over-dependence on fossil fuel could be seen in light of both gas-fired and coal-fired plants being run as base load plants, while Renewable Energy plants especially large hydro stations are committed during peak load, thus being called peakers. (Malaysia Technology Master Plan, 2016)

It is crucial to reduce dependence on coal in compliance with the GHG emission reduction pledge at the United Nations Framework Convention on Climate Change (UNFCCC) 21st Conference of the Parties (COP21). In the medium term (2016-2020) and long-run (2021-2030), the Government is keen on more sustainable and green energy initiatives. It is time to make a definitive position to reduce fossil fuel consumption especially coal. The coal-gas combo shall be reduced to manageable quantum (e.g. $80 \%-85 \%$ by 2030 ), by imposing a Herfindahl - Hirschman Index (HHI) of 0.5 on any fuel source and mandate steady stream of Renewable Energy takeoff including large hydro power stations.

In current scenario, waste management and renewable energy are mainly cost and implication on sustainability issues. As cited in Nnaji 2015, China has overtaken the USA as the largest waste generator with an annual waste generation of 190 million tons in 2004 and a projected 480 million tons by 2030 (Minghua et al., 2009). In Hong Kong, The annual costs of the Government's waste collection and transfer service amount to another $\$ 435$ million and $\$ 355$ million respectively. These have resulted in the complexity of the waste composition being generated and contributed to the ever-increasing waste generation per capita.

More the less, Hai and Ali (2004) also highlighted the pathetic state of solid waste service provision in Bangladesh. In India, solid waste management is poorly developed (Saha et al., 2010) and has become a major environmental challenge (Devi et al., 2014). To add to this issues, In Kenya, waste collection systems are inefficient and disposal systems are not environmentally friendly such that 30-40 percent of all solid waste generated in urban areas is uncollected and less than 50 percent of the population is served (Gakungu et al., 2012). At a policy level, the European Commission (EC) through its Environment Directorate-General, presents a relatively strong view about the critical importance of sustainable development and the implications for Europe and beyond. Gertsakis and Lewis 2003 stated that In Australia, the key strategies for sustainability include radical improvements in eco-efficiency, the closing of material and waste cycles (eliminating waste) and a shift from products to services such as dematerialization.

In Victoria, Australia, the hierarchy is embedded in the Victorian Environment Protection Act, specifically stating that wastes should be managed in accordance with the following order of preference: avoidance, re-use, re-cycling, and recovery of energy, treatment, 
containment and disposal. EcoRecycle Victoria through its various industry, government and community programs is the key agency for developing and facilitating strategies that help operationalize the hierarchy in relation to solid waste. Their role has been a major influence in moving certain industry sectors and specific companies away from simply transporting and managing waste, and closer to resource recovery and associated market development programs. (Gertsakis and Lewis 2003)

According to Gertsakis and Lewis (2003), the Australis's Guideline for Sustainable Energy from Waste Project Development developed by the Waste Management Association of Australia (WMAA 2001) proposes a number of principles for energy recovery from waste. It is objected that a potential fuel source not be irreversibly converted to energy if it still retails a 'higher' value as a basic resource material.

Historically, Germany has been much more reliant on domestic coal and nuclear to meet its energy needs. But German Chancellor Angela Merkel is phasing out coal and nuclear, leaving many to conclude that natural gas is going to have to make up that difference. The German Association of Energy and Water Industries, shows that renewable energy - mostly wind and solar - generated 118 billion kilowatt hours $(\mathrm{kWh})$ of electricity in the first half of the year, compared to $114 \mathrm{kWh}$ generated from lignite and hard coal. The transformation of renewable energy evolves in the developed countries.

\subsection{Sewage Sludge in Malaysia and Other Countries}

In Malaysia, Indah Water Konsortium (IWK) is responsible for planning and rationalizing the public sewerage facilities to reduce the number of treatment plants using the "multipoint concept" or regionalization. Finally, sewerage pipeline networks will be layed in urban areas currently serviced by Individual Septic Tanks (IST) to convey the domestic sewage to modern secondary treatment facilities.

According to IWK 2018, in Malaysia extensive use has been made of primary treatment systems such as communal septic tanks and imhoff tanks and unreliable low cost secondary systems such as oxidation ponds. In addition, large urban areas utilize Individual Septic Tanks (IST). It is estimated that there are over one million individual septic tanks in Malaysia.

These tanks only partially treat sewage, discharging an effluent still rich in organic material. This has the potential to create public health and environmental problems, particularly in urban areas. In Malaysia, $38 \%$ of public sewage treatment plants in the country are mechanical plants. These plants operate using mechanical equipment that accelerates sewage break down.

According to Zsirai (2010), global production of sewage sludge is beyond of approximately 50M Tds/a, which amount enables to consider Sewage Sludge seriously as a special resource for conversion to renewable energy. In EU27 the current utilization of the sewage sludge is as follows: (1) Recycle to land, 42\%; (2) Incineration, 27\%; (3) Landfill, 14\%; (4) Other, 16\% ; The expectation is for 2020 that the Landfill ratio will be heavily decreased , Incineration will be slightly increased and other Sludge to Energy technologies will be promoted and get larger percentage of market share.

As an example, we should look at the Member States of EU and compare the ratio of the renewable energy in different States vs. national energy mix. Results show large discrepancies due to available natural resources and geographical \& topographical positions. Countries with the largest ratio demonstrate huge "Hydro" energy investment and usage. The most beneficial users are Austria 70,4\%, Sweden 46,4\% Luxemburg 27,0\%, Italy 19,6\%, Portugal 19,5\%. The most unbeneficial are England 2,4\%, Belgium 1,9\% (Zsirai, 2010)

In 1999 the United Kingdom (UK) produced 1,130,066 tonnes of sludge dry solids. This averages to about 20kg generated by each person. Historically in UK, about a quarter of sludge was either dumped at sea or discharged to surface waters. This was banned from 1998 under the Directive because it was considered environmentally unacceptable.

Zsirai (2010) has stressed out that sewage sludge can also be used to produce renewable energy, which reduces our impact on climate change. Sewage sludge is an inevitable and unavoidable by-product of sewage treatment. In relation to sewage sludge and renewable energy, the global renewable energy distribution market share as per actual status, are wind, $40 \%$; hydro, $32 \%$; biomass, $19 \%$; sewage sludge to energy , $<3 \%$; solar PV, $<1 \%$; solar concentrated, $<1 \%$; geothermal, $<1 \%$; tidal, $<1 \%$; solid waste landfill gas to energy, $<1 \%$; and others, $<1 \%$ respectively.

From these facts from different countries about sewage sludge and renewable energy, there are indications that show that there is a potentiality of transforming sewage sludge into renewable energy. Reflecting the data from this exploratory study, the proof and evidence from other countries may be replicate in Malaysia in transforming the sewage sludge into renewable energy. The above scenarios value and wealth creation from transforming waste into renewable energy can be illustrated in an economic theory as follows:

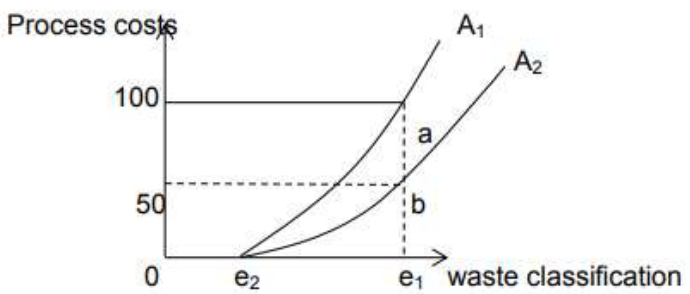

Diagram 1: Waste Classifications and utilization of renewable resources.

This economic theory explains about the relationship of cost and waste classifications quality in producing renewable energy. The vertical axis is processing costs, and the horizontal axis is the amount of waste classification. We can see that when our amount of wastes is classified more and more, it causes the reduced processing costs, and ultimately increases environmental quality and finally 
increases the quantity of renewable resources. (Sun, Qu \& Li, 2013). Therefore, it is understandable that, the better the way we manage our waste, the higher the benefits of cost reduction and wealth creation as well as increases the quality of life.

\subsection{Methodology}

This exploratory study use qualitative measures. This research is designed to reveal various past findings and reviews on the perceptions that drive it with reference to specific topics or issues. It uses in-depth studies to support the construction of hypotheses. This study examined the current issues on waste management particularly in sewage sludge and its potential of value and wealth creation by transforming sewage sludge into new source of renewable energy in Malaysia.

The qualitative approach is done by gathering data on past research and literature reviews about waste management particularly on sewage sludge and renewable energy in Malaysia. This study was executed by a combination of an extensive literature search. The qualitative methodology of the interpretative paradigm is regarded as the qualitative approach as it mainly emphasizes detailed explanations of cases with socially constructed meaning (Neuman, 2006). The extensive literatures refer to the data and information regarding waste management, sewage treatment in Malaysia, as well as the government policy such as Feed In Tariff (FiT) on value creation on waste management and renewable energy.

The evidence and proof from other research from many countries on sewage sludge transform into renewable energy are gathered, the critically analyzed in reflect to the current state of Malaysia. In conducting this explorative methodology, this study looks into the current scenario analyzing the policy Malaysian government towards creating value and sustainability particularly on the area of sewage sludge transformation into renewable energy. Consequently, its output is to add new knowledge, develop theories as well as gathering evidence to prove generalizations (Sekaran, 2000).

\subsection{Findings \& Analysis}

Abor (2012) stressed out that waste is a higher risk when it is hazardous and should be handled with care. The Eleventh Malaysia Plan (2016-2020) or RMK-11 has outlined inclusiveness and sustainability as the key pillars where the pursuit of green growth for sustainability and resilience will be a game changer, shifting from the old "grow first, clean up later" model. There will be fundamental shifts in the utilization of natural resources and the environment for socio-economic development. In the next five years, the Government will focus on strengthening the enabling environment, promoting sustainable consumption and production, conserving natural resources, and strengthening resilience against climate change and natural disasters.

In Malaysia's Green technology Master Plan 2016, efforts have been put into place by the Malaysian Government to ensure the long-term sustainability of the energy sector through resource diversification, continuous investment in new infrastructure and state-ofthe-art technology deployment. Currently, the relevant products and services are deemed affordable only to certain income group and those who are well-aware of the climate change and global warming issues. Future energy prices are greatly influenced by the global economic performance. The current rate of energy consumption for building operations, the associated GHG emissions, and the uncertainties in future prices of coal, natural gas and electricity can be a cause of concern for policy makers and industry players.

The aspirational targets for installed Renewable Energy capacity are set at $20 \%$ in $2020,23 \%$ by 2025 and $30 \%$ by 2030 as compared with $18.9 \%$ in 2016. However, it is conditional on the leveled cost in each Renewable Energy source is close to conventional resources, with no new major coal-fired power plants established post 2020.

Historically, Germany has been much more reliant on domestic coal and nuclear to meet its energy needs. The German Association of Energy and Water Industries, shows that renewable energy - mostly wind and solar - generated 118 billion kilowatt hours (kWh) of electricity in the first half of the year, compared to $114 \mathrm{kWh}$ generated from lignite and hard coal. The transformation of renewable energy evolves in the developed countries.

Since future energy prices are greatly influenced by the global economic performance, the potential value creation from transformation of waste into renewable energy is an opportunity. In developed country such as Germany, waste management has evidently proven has a potential to be transform into renewable energy. Therefore, with the same principles, Malaysia also has the same potential. These reflected by the initiatives taken by the Malaysian government by introducing many policies that encourage renewable energy. As compared to the other developed countries, the implementation phase for RE in Malaysia is considered new given Malaysia Technology Master Plan has outlined that the transformation of waste to energy thermal plants in that in 2020, the country will at least has 1 waste to energy thermal plant in Malaysia.

Jose \& Zafia (2012) describes that there is a relationship between waste and value that needs exploration. It visualizes a project whose value and waste are intrinsically related. Economic instruments are essential to create the monetary value. This includes both physical and non-physical economic instruments. Physical infrastructure support such as charging station, waste transfer station, rail tracks and others are deemed to be provided by the Malaysia's Government.

According to Rospidah \& Adnan (2011), a renewable energy source may provide a cost-effective option for the electrification. When waste is entangled in the project delivery process, it also becomes -embeddedll in the project because resources that could have been used for the generation of value were instead consumed for the generation of waste (Jose \& Zafia 2012). In relation to this, the generation of value can be best experienced through the Energy Policy of Malaysia whereby Non-physical economic instruments cover incentives and subsidies such as Feed-in Tariff (FiT), Investment Tax Allowance (ITA), Pioneer Status, carbon trade, technology transfer and others. (Green Technology Master Plan 2016). 
Gertsakis and Lewis (2003) agrees that transforming waste into renewable energy is an economic impact that creates New business opportunities in waste treatment. The policy of Feed In-Tarif (FiT) in promoting renewable energy in Malaysia may encourage many industry players to be in the industry in order to promote the government policy thus eventually impacted in sustainability of the and green economy environment. Vaghefi, Chamhuri \& Sarah (2017) agree that Greening the economy could increase wealth, economic growth, proper employment, reduced poverty, and social equity.

According to Rospidah \& Adnan (2011) the Green technology is earmarked as an important driver for the twin goals of high income and sustainability. Evidence of convergence of the three goals includes Malaysia's success in attracting $\$ 4$ billion worth of foreign direct investments to the solar photovoltaic industry.

Outlined by Rospidah \& Adnan (2011) as an upper middle income country, Malaysia aims not only to graduate into the high-income category in the short term by year 2020, but also to strengthen its economic foundation in order to shift to a new period of low carbon green development (Hezri and Dovers 2011). According to Zsirai (2010), the potential for renewable energy generation from sludge on a national level is enormous. Access to inexpensive, renewable energy will become even more important because the cost of sewage treatment is bound to rise.

Thus, by looking at the current practice in other developed countries about waste management particularly in sewage sludge, and valuing waste into transformation of renewable energy, the waste management of sewage sludge in Malaysia has a potential of value and wealth creation. Given the policy by the government on Energy Policy of Malaysia is constructive in promoting wealth in the industry. Vaghefi, Chamhuri \& Sarah (2017) stated that government intervention which supports the economy in determining the direction and level of technological changes plays a crucial role in determining the future nature of the Malaysian economy. The Malaysia's regulatory framework may boost the incentives of the government to align the value and wealth creation in waste management and renewable energy particularly in sewage sludge area.

\subsection{Conclusion \& Recommendation}

Malaysia's national green economy attempts to strengthen the economy via incentives, the tax system, pricing, regulatory frameworks and prioritized investments. Since 2009, the Malaysian government established the basic architecture for green economy by incorporating a green technology portfolio into the Ministry of Energy, Green Technology and Water. The fact that "improving the quality of life for all' is one of the four pillars of Malaysia's National Green Technology Policy which supports sustainability and green economy. The finding from this study reveals that, there is a potentiality of value and wealth creation when managing waste particularly sewage sludge to turn waste into a source of wealth through waste recovery for material extraction and conversion of waste to energy. The value and wealth creation can be optimized by using the current policy of Energy policy in Malaysia. The energy policy of Malaysia promotes renewable energy through the incentives and tariff given to the industrial player whom can produce the renewable energy. Given the policy, any institution is entitled to experience these economic benefits if they are able to contribute to the production of renewable energy. Given to the condition of transforming sewage sludge into renewable energy, thus it is concluded that the economic value can be thus created from the economic incentives of the tariff given to the industry player in renewable energy. Thus this situation can be positively contributed to the sustainability of Malaysia. This study concludes that there is a potential of value and wealth can be obtained from waste management conversion into renewable energy.

This supported from the evidence from the Malaysia's government policy on renewable energy. Conceptually, wealth creation comes from the economic instruments of incentives and subsidies such as Feed-in Tariff (FiT). Another synergistic value from this conceptual model is it promotes green economy and sustainability of the environment. The contribution of the study reveals that by transforming the sewage sludge, the environmental problems such as waste landfills can be reduced. In fact, in other contries, cost savings through better solid waste and fecal sludge composting in Asia and Africa could reach several billion US\$ per year, assuming a market for $25 \%$ of the generated urban organic waste (CGIAR, 2013). The phase of implementation of the waste into renewable energy particularly on sewage sludge in Malaysia can be concludes as new phase or beginning era. Therefore, in future years it is expected that there will be a lot more potential players in the industry to take the opportunity to create value and wealth from this field.

Since this study is exploratory stage, although there is a potentiality in creating value in sewage and renewable energy as referred the data from European countries, however in Malaysia, there is not much proof and evidence in relation to this kind of study. Therefore it is recommended that future research should concern on the value creation of sewage sludge as a source of renewable energy. Particularly, it is recommended that further quantitative study should be done on sewage sludge as a source of renewable energy specifically on the value and economic impact towards sustainability and green economy of Malaysia.

\section{References}

Abor P. A. (2013). Managing healthcare waste in Ghana: a comparative study of public and private hospitals. International Journal of Health Care Quality Assurance Vol. 26 No. 4, 2013 pp. 375-386

CGIAR Research Program on Water, Land and Ecosystems, Creating Wealth from Waste: Business Plan Draft, April 2013

Devi, K., Swamy, A. and Krishna, R. (2014). Studies on the solid waste collection by rag pickers at Greater Hyderbad Municipal Corporation, India. International Research Journal of Environmental Sciences, Vol. 3 No. 1, pp. 13-22. 
Environmental Protection Department (2016). Environment Hong Kong 2016, A Policy Framework for the Management of Municipal Solid Waste 2005-2015, Hong Kong. Retrieved at June 20, 2018, from www.enb.gov.hk/www.epd.gov.hk

Gakungu, N., Gitau, A., Njoroge, B. and Kimani, M. (2012). Solid waste management in Kenya: a case study of public technical training institutions. ICASTOR Journal of Engineering, Vol. 5 No. 3, pp. 127-138

Gertsakis, J., Lewis, H. (2003). Sustainability and the Waste Management Hierarchy - Discussion Paper EcoRecycle Victoria.

Hai, F. and Ali, M. (2004). A study on solid waste management system of Dhaka City Corporation: effect of composting and landfill location. UAP Journal of Civil and Environmental Engineering, Vol. 1 No. 1, pp. 18-26.

Hezri, Adnan; Ghazali, Rospidah (2011). A fair green economy? Studies of agriculture, energy and waste initiatives in Malaysia. UNRISD Occasional Paper: Social, Dimensions of Green Economy and Sustainable Development, No. 2, ISBN 978-92-9085-082-3

José L. F., Zofia K. R. (2012). A Theory Of Waste And Value. International Journal of Construction Project Management ISSN: 1944-1436 Volume 4, Number 2

Malaysia Energy Policy, Focusing on Sustainable Energy Development and the Way Forward by Ministry of Energy, Technology, Science, Climate Change and Environment (KeTTHA) 2016

Neuman, W. L. (2006). Social Research Methods: qualitative and quantitative approaches (6th Edn). Sydney: Pearson International Edition.

Nnaji C.C., Status of municipal solid waste generation and disposal in Nigeria. Management of Environmental Quality: An International Journal Vol. 26 No. 1, 2015 pp. 53-71

Sekaran, U., Bougie, R. (2013). Research methods for Business: A Skill Building Approach. John Wiley \& Sons Ltd. Sewage Sludge in Germany. Retrieved on September 15,2018 , from

https://www.umweltbundesamt.de/sites/default/files/medien/378/publikationen/sewage_sludge_management_in_germany.pdf

Sewage Sludge Indah Water Konsortium, retrieved April 3, 2018, from https://www.iwk.com.my/customer/sludge-treatment Sun P.Y., Qu L., \& Li X., Waste disposal and renewable resources, Bachelor Thesis Report, 2013

Sun P.Y., Qu H., and Li X.,(2013), Waste disposal and Renewable resources, Bachelor Thesis Report

Vaghefi, N Chamhuri S, Sarah A.G.A. (2017) Building Malaysian Green Economy Model for Socio-Economic Development. International Journal of the Malay World and Civilisation (Iman) 5(Special Issue 1), 2017: 27 - 32

Zsirai, I. (2010, September 9\&10). Sewage Sludge As Renewable Energy. Paper presented at 2nd European Conference on Sludge Management, Budapest, Hungary. 